\title{
Managing Central-Local Government Relationships: The Case of New Zealand
}

Commonwealth Journal of Local Governance

\section{Michael Reid}

Principal Adviser

Local Government New Zealand

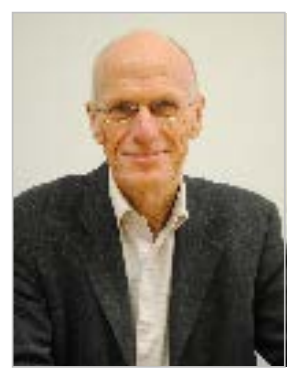

\begin{abstract}
The manner in which central and local governments engage has taken on extra salience in recent years as governments seek to address wicked issues and begin to appreciate the role of place as a key contributor of economic growth. Different approaches exist, ranging from formal and constitutional to informal and political, but none represents a magic bullet with outcomes always subject to local circumstances. In this context the example of New Zealand highlights a particular challenge; how to maintain effective of inter-governmental relationships in the absence of either constitutional recognition of local government or a formal agreement between the two sectors.
\end{abstract}

In 1839, within six months of arriving in Port Nicholson ${ }^{1}$ after leaving their home country of England and a year before the signing of the Treaty of Waitangi which gave Britain legal oversight, the 1400 or so new settlers agreed to establish a council to provide order in the new town, reflecting "those constitutional principles which every Englishman (sic) is taught to regard as his birthright” (Carman 1970 p. 25). Within months of the council's formation a furious Lieutenant-Governor Hobson, the British Government's representative in that country, concerned at such an affront to his authority arrived in the barque Integrity, accompanied by 30 troops and constables, to close such "high treason" down. It was an event that in a number of ways has characterised local government's relationship with central government since that time. It was an inauspicious start to local central relationships. ${ }^{2}$

\footnotetext{
${ }^{1}$ Port Nicholson was the early settler name given to what is now known as Wellington, the capital of New Zealand.

2 The phrase central-local government relations is used to describe relationships between local governments and either state or provincial governments in federal systems or central governments in unitary systems. In New Zealand local government incorporates regional councils.
} 
While it is much less common today for higher level governments to send warships to sort out their unruly local colleagues, finding the optimal mechanisms for managing inter-governmental relationships remains unfinished business, influenced as it is by local government's constitutional position and is heavily path dependant. Finding the appropriate mix of roles between local and central governments is necessary, as the business of governing requires an ability to balance the differing needs and expectations of both local and national communities. Meeting the social and economic needs of communities is seldom achieved by the actions of the centre acting alone, and clever governments manage to address the national interest while allowing diversity and difference to flourish at the sub-national level. The policy question, for those responsible for designing governance systems, is how to enable local and regional innovation within a national framework - in other words how to recognise the mutual roles of governments at all levels. Consequently managing intergovernmental relationships is a public policy challenge that few countries have satisfactorily resolved. It remains a particularly salient issue in New Zealand.

\section{Governing as a multi-stakeholder exercise}

In its briefing paper to the incoming government in November 2011, Local Government New Zealand (the local government association) requested that the relationship between local and central government should be governed by some form of jointly negotiated agreement. As proposed by the association the agreement would set out the mutual expectations of each sphere of government towards the other and provide a basis for negotiating shared goals. At the time of writing there has been no response to the association's request. In fact, rather than the partnership envisaged by the association, the Government appears to be committed to a much more 'hands on' approach to managing if not controlling the performance of its local governments; concepts of shared goals are mere afterthoughts when compared with the twin goals of efficiency and productivity. Yet agreements do seem to be of increasing interest internationally, whether to recognise the value of local collaboration or as relatively frugal mechanisms through which to influence the behaviours of sub-national governments.

The notion of spheres of government engaging in dialogue to achieve some form of improvement in community well-being reflects a new appreciation of the business of governing (Kjaear 2004, Leuprecht and Lazar 2007). The value applies across policy domains, for example, the value of coordination was specifically recognised by the Organisation for Economic Cooperation and Development (OECD) in its study of regulation in Ireland when it noted that: 
Local governments within the boundary of a state need increasing flexibility to meet economic, social and environmental goals in their particular geographical and cultural setting... this requires a pro-active consideration of:

- The allocation/sharing of regulatory responsibilities at the different levels of government.

- The coordination mechanisms between different levels of government (OECD 2010, p. 153).

The OECD goes on to recommend that the coordination and consultation mechanisms operating between local and central government in the Irish Republic should be reviewed with the objective of strengthening existing mechanisms. It specifically mentions the possibility of holding an annual forum. The OECD's report on regulation within the Republic also acknowledges that good governance is what we might describe as a multi-stakeholder exercise which places particular emphasis on both spheres of government having effective coordination mechanisms. The analysis reflects the growing influence of governance theory on the topic of inter-governmental discourse (Kjaer 2004, Albrow 2001). Governance theory itself tends to focus on:

- The existence of multiple stakeholders, particularly in relation to collective problems that cannot be solved by the public sector working by itself but requires the co-operation of other players (for example, citizens, business, voluntary not-for-profit sector and media);

- The presence of formal rules (such as constitutions, laws and regulations) and informal rules (such as codes of ethics, customs and traditions);

- The role of market and quasi-market structures (as a form of steering), hierarchies (such as bureaucracies) and co-operative networks (as possible structures for facilitating change in some situations) (see Loffler 2003).

In short governance is concerned with the behaviour of multiple actors and involves the formation and stewardship of rules, both formal and informal, that control the public space in which economic and social actors interact to make decisions. This process is underpinned by negotiation, "the means for achieving direction, control, and co-ordination of individuals and organisations with varying degrees of autonomy to advance joint objectives” (Kjaer 2004, p. 282).

Simply put, governance involves operating across institutional boundaries in a context where traditional command and control approaches are increasingly inappropriate and ineffective in order to address particular problems. Consequently a new set of governing skills is required, skills that recognise the autonomy of agents and place more emphasis on persuasion and negotiation than direction. It is a challenging prospect for higher level governments where the normal local central government relationship is strongly hierarchical and the narrative is concerned with managing risk 
and strengthening accountability. A focus on governance also raises questions of formality and whether or not relationships can over time move from informal to formal in order to compensate for the constitutional weakness of many local government systems.

\section{The nature of engagement}

One of the public policy issues that all governments confront at some point is how best to engage with their local and regional governments. Should the relationship be hierarchical, reflecting their relative constitutional positions, or more of a partnership, recognising their complementary roles in governance? Alternatively, should the relationship have elements of both? 'Engagement' is a term that has become increasingly popular for describing, what is frequently, a broad church of interaction between spheres of government (Aulich et al 2011). It implies a meaningful interaction but stops short of a commitment to ongoing collaboration or partnership, although both might be a consequence of good engagement. It occurs across a range of dimensions, from the operational and policy dimensions to the political. While operational and policy engagement tends to be strongly issuefocused and driven by events, for example the joint response to the Christchurch earthquakes, the political dimension is considerably more complex particularly in local government systems lacking a strong 'formal' political party presence.

Engagement implies at the very least two parties that, while not being equal in constitutional terms, participate as independent entities. While constitutional authority will frequently lie with higher spheres of government, a range of measures - from legislative and regulatory to persuasive - can be employed to 'steer local governments'. This paper is primarily concerned with the non-coercive dimension of those relationships which primarily involve dialogue and what might be called institutionalised discourse.

In their study of what makes successful cities, the Fannie Mae Foundation (2007), a US think tank, noted two principles that higher level governments should ascribe to in their relationships with local government. One was the simple principle of 'do no harm', reflecting the ever-present danger of unintended consequences when governments intervene. The other was the desirability of enabling local governments and their representative bodies to contribute to decision-making processes that have the potential to impact directly on citizens. In the Foundation's view, local governments play a 
critical role through their ability to critique proposals put forward by national and/or state legislators and to identify potential negative impacts. ${ }^{3}$

Diminishing or avoiding harm and providing opportunities to contribute to decision-making necessarily implies some form of engagement, and indeed agreement, and a range of models exist. New Zealand has gone some way towards achieving this by its practice of holding an annual meeting between local government leaders, the Prime Minister and senior Cabinet Ministers. ${ }^{4}$ However, New Zealand is not the only country to experiment with new institutional mechanisms for enhancing engagement. We see continual evidence that governments and associations throughout the world are working on innovative and constructive approaches to improve engagement, and many offer interesting lessons.

The constitutional context of inter-governmental relationships in unitary countries is nicely captured by the central-local concordant, signed between the English Parliament and the Local Government Association in 2007, which states:

Central and local government both derive their legitimacy from Parliament and the electoral mandate granted them by individual citizens who look to central and local government to take the lead in ensuring better places and better services (DCLG 2007).

The Concordant goes on to argue that this shared mandate means that both central and local government are effectively partners in delivering improved services and strengthening democracy. While central government has responsibility to act in the national interest, councils have a similar responsibility in relation to the interests of citizens in communities defined by place. It is a statement, however, that demands some clarification as to how the boundary between the national and local interest should be defined - a question for which there can never be a simple answer and which is clearly negotiated within particular contexts and influenced by the nature of inter-governmental relationships. Not surprisingly approaches to engagement vary, reflecting countries' different constitutional settings, historical patterns of development and the varied preferences of political actors, both local and national.

\footnotetext{
${ }^{3}$ A particular sore point is New Zealand where government departments often develop detailed legislative proposals that directly affect local government without consultation.

${ }^{4}$ In 2007 the President of Local Government New Zealand (the local government association) was invited to brief the House of Common's Local Government Select Committee about the way in which engagement between the two spheres of government in New Zealand was operating.
} 


\section{Why engage?}

The emergence of multi-level governance "challenges much of our traditional understanding of how the state operates, what determines its capacities, what its contingencies are and ultimately the organisation of democratic and accountable government” (Peters and Pierre 2001, p. 131). Formal constitutional arrangements are today less aligned with the locus of political power, which is increasingly found in the ability of agencies to coordinate resources drawn from both public and private interests. The command and control state is shifting towards an enabling state, more concerned with defining objectives and mustering resources (Peters and Pierre 2001, p. 131), with the result that the process of governing is more about aligning and steering than directing. This is particularly relevant to spheres of government, national, provincial and local.

Higher level governments have a number of reasons for wishing to influence the behaviour of their sub-national colleagues, including engagement with national local government bodies. These include for example:

- To encourage councils to voluntarily promote the government's (national) objectives, such as to support efforts to grow the economy or contribute to initiatives to ameliorate climate change;

- To diminish the risk of councils undermining the government's (national) objectives, for example, by failing to invest in local infrastructure with the risk of municipal service failure and investor flight;

- To make use of locally gained knowledge and experience in order to improve the development of national policies and programmes;

- To help resolve conflict, particularly where additional mandates, especially unfunded mandates, have been imposed on local government (Gormley 2006).

The overriding motive, however, is likely to be to protect the national interest, whether from fiscal risk or to protect a landscape of national importance. To achieve their objectives governments possess a number of instruments with which to influence the behaviour of councils - these range from instruments which are coercive and direct, like legislation and regulation, to instruments that are noncoercive and indirect, such as tied grants, training incentives and investment in best practice. In reality, however, the number of coercive instruments governments can use without either diminishing local democracy (which is the point of local government), or creating substantial costs and community resistance, is limited. Legislation is not inexpensive; there is competition for both analyst and parliamentary time and the risk that a government's original objective might be lost as draft 
legislation works its way through the system is ever present. Consequently using less direct and more persuasive steering mechanisms is increasingly favoured (Dollery and Wallis 2001).

It is a trend that appears to be occurring in many OECD countries with a shift away from prescriptive and hierarchical steering approaches, which are often expensive to implement, to approaches based on voluntary compliance. For example, Banner (2002) argues that in the future governments will make increasing use of three dominant steering strategies, each of them a "bottom-up" form of steering.

These are:

- Empowering the market through measures that require councils to subject their activities to competitive testing. This a form of 'non-steering' which operates on the basis that the appropriate direction is whatever the market chooses. In New Zealand the best example is the requirement that councils receiving roading funds from the New Zealand Transport Agency must put all projects out for competitive tender;

- Empowering the community through enabling greater participation in council affairs and increased voice. In New Zealand this strategy is given expression through the requirement that councils publish draft plans and budgets and subject them to formal consultation with citizens; ${ }^{5}$

- Increasing transparency and promoting a "sustained public discussion on City Hall performance" (ibid p. 227). In New Zealand the requirement on councils to develop and publish ten year financial strategies and more recently publish pre-election reports describing their financial circumstances are all intended to promote sustained dialogue on performance. A framework that removes the government from hands-on steering (using instead markets and citizens themselves) reduces the need for "top down" direction and improves the opportunity for local and central government to engage as equals or partners.

From a local government perspective there are two major reasons for formalising relationships between spheres of government. The first, and instrumental, approach is very simply an attempt, particularly by sub-national governments, to gain a greater role in decision-making about their own roles and legislative frameworks. We might speculate that this approach is likely to be stronger in countries where local governments lack constitutional recognition and face an unstable and uncertain legislative environment - effectively operating at the whim of whichever party secures a majority in the national or state parliament. These relationships are likely to stress principles guaranteeing early involvement in the design of central or provincial policies and regulations directly affecting the local

\footnotetext{
${ }^{5}$ Tellingly in her speech to the third reading of the Local Government Bill 2002 the then Minister of Local Government, the Hon. Sandra Lee, stated that this bill is not about empowering councils but rather empowering citizens to control their councils.
} 
government sector. ${ }^{6}$ The second rationale is more pragmatic and views engagement as necessary to address so called "wicked issues". Wicked issues, or malignant problems, are issues which have the following characteristics:

- There is no definitive statement of the problem (and there may be disagreement on its nature);

- Without a definition the search for solutions is open-ended, with a tendency for people to frame "problems" to better connect with their preferred solutions;

- The problem-solving process is complex because constraints, such as resources and political ramifications, are constantly changing;

- Constraints change because they are generated by numerous interested parties, which selectively choose to share information and may change the rules by which the problem must be solved (Roberts 2000).

Addressing wicked issues inevitably requires multiple collaborations and predicates a shift away from governments as providers of services to one of governing - an exercise that is inherently collaborative.

As Kooiman argues:

No single actor, public or private, has all the knowledge ad information required to solve complex, dynamic and diversified problems; no actor has sufficient over view to make the application of needed instruments effective: no single actor has sufficient action potential to dominate unilaterally in a particular governing model (Kooiman 1993:4 in Kennett 2010).

If we accept that governing is a task that occurs amongst multiple public and plural institutions, then we are left with an understanding that governing is inherently messy, that is, it represents a policy space where rules and command and control approaches are unlikely to work and new instruments are required which balance 'top down' and 'bottom up' approaches. From a local government perspective, councils' generally subservient constitutional status means that engagement is, if nothing else, a form of risk insurance which ensures that national decision-makers are aware of local government's views when developing policy and making decisions. Yet engagement is more than simply good risk management, other rationales include:

- That councils provide citizens with a mechanism for making decisions about the way their cities, districts and regions are governed. Councils need to engage with central government in order to ensure they have the 'tools' and frequently the resources to meet community expectations and

\footnotetext{
${ }^{6}$ For example, an ongoing cause for concern expressed by members of New Zealand and Australian local governments has been the tendency for higher level governments to design policies and programmes for local government implementation without any consultation with local government.
} 
develop innovative solutions to local issues. Addressing local expectations often means 'lining up’ government departments working in the district;

- That because of their role in communities, councils acquire considerable knowledge and information about community issues and concerns. Engagement enables this information to be brought to the attention of the government and its departments and consequently inform policy and operational decisions affecting particular localities. Accepting the role that 'place' plays in national economic development, engagement enables local authorities to seek support from higher level governments for proposals that may have both local and national benefits;

- That effective relationships at a national level can also be used to model relationships between individual councils and government agencies, enabling local and central government officials to build relationships in order to increase understanding of each others' roles and how they contribute to common outcomes. Alignment can reduce the risk of unnecessary duplication and provides opportunities for officials from both sectors to identify more innovative and effective solutions to common problems. Initiatives introduced by New Labour in England, such as Local Area Agreements (LAAs) and Total Place, were ways of attempting to provide institutional form to such collaboration. The current Conservative Liberal democratic government continues to experiment with similar approaches.

\section{Place as a driver for engagement}

If there was one particular justification for an increased interest in inter-governmental engagement over recent years it is the perception that 'place' matters, that despite the growth of technologies which create new communities of interest, communities based on geography continue to play a critical role. Michael Lyons' inquiry into local government (Lyons 2007) tackled this question head on and concluded that the local role was becoming stronger as society becomes more diverse. Noting that different local authority areas have different views on what constitutes the good life. Lyons quotes the Tavistock Institute which suggested that in the future:

Many of the pressures on government will manifest most dramatically at a local level. More flexibility and responsiveness at a local level would significantly enhance government's capacity to meet those challenges successfully (Lyons 2007 p. 57).

Economic policy globalisation and the mobility of skilled workers makes place an important asset, and local governments are well placed to engage with citizens and work with local partners to plan and deliver services to meet community priorities. In addition there has been a growing acknowledgement of the importance of cities as a locus of growth, innovation and investment (Albrechts 1991). If cities are to achieve their potential, and in doing so contribute to national 
economic and social well-being, then councils will need to not only maintain but to increase their investment in city infrastructure, both soft and hard. In a world of constrained choices Lyons suggests that local choice, exercised through a democratic framework, to prioritise resources in the face of competing needs is critically important.

In the face of growing diversity and information asymmetry, national governments often lack the policy capacity and legitimacy to ensure successful outcomes at a community level and are poorly suited to deliver policies and programmes to communities with diverse preferences (Oates1972). In a world in which innovation and knowledge have become the attributes of success, institutional arrangements which disperse public decision-making and empower citizens to have greater influence over how decisions are made are more likely to prosper. Lyons has drawn on the concept of place in his approach to governance. This is reflected in the notion of 'place-shaping' defined as the "creative use of powers and influence to promote the general well-being of a community and its citizens" (ibid p.60). Particular aspects of the place-shaping role include building and shaping local identity; understanding local needs and preferences; representing the community and local partnerships.

It is in the context of place and its importance to the outcomes that governments seek to promote that the topic of central-local government engagement has become of greater interest, not only to the parties involved but also to academics and commentators.

\section{The dynamics of engagement}

Much of the academic interest in engagement is drawn from the European context where councils play a major role in the delivery of social services, and where failure of local governance is likely to deliver diminishing outcomes to citizens. Comparative studies tend to focus on the different factors that influence the interface between spheres of government and seek to answer the question why it works well in some societies and not in others. Blom-Hansen (1999), for example, notes that the characteristics of inter-governmental relationships vary considerably across jurisdictions and are influenced by:

- the nature of the constitutional makeup, whether it is federal or unitary;

- the existence and strength of political parties;

- level of urbanisation;

- the nature of the welfare state - decentred or not;

- the nature of the recruitment patterns to national parliaments;

- the historical backgrounds of the local government systems. 
The result is a range of factors that determine the nature of the central-local government relationship, which may also vary according to policy area. Governments will take a stronger interest in those activities of local governments that affect the national interest than those which are purely local in impact. In New Zealand, for example, this is particularly noticeable in relation to local government's role in environmental management and land use, with increasing central government intervention (using a command and control approach) in relation to urban growth and the effect of metropolitan urban limits. The government is concerned that national policies focused in creating more affordable housing might be put at risk by council policies favouring more compact cities.

In addition to Blom-Hansen's list of factors we might add the influence of local actors or agents. The interface between central and local government is a dynamic one, constantly evolving and affected by the attitude and performance of key agencies, such as government departments and individual local authorities. Governments cannot act as free agents. Although Parliament may have the authority to abolish local government it ultimately depends on the resources of councils and other local actors for political support, information, expertise and the implementation of policies. As a result the 'nuclear' option, that is the removal altogether of the local government system, is not one that we have seen exercised in advanced democracies. While formal structures, such as constitutions or parliamentary conventions, set the context for relationships it is often the informal networks, local and national, that have a significant influence on what happens. Formal institutions are in fact underpinned by informal policy networks in which central government actors interact with other actors, such as local government staff and local politicians. One way of describing the nature of these inter-governmental relationships involves distinguishing between three types of actors: Topocrats, Expenditure Advocates and Expenditure Guardians (Blom-Hansen 1999).

- Topocrats are the representatives of sub-national governments, usually associations set up to defend the interest of their members at the national level. Blom-Hansen argues that these associations are increasingly important in national policy making and act as guardians of local government interests in the national political process. Their default focus tends to be to protect the autonomy, fiscal viability and integrity of the particular level of government they speak for.

- Expenditure Advocates are actors in the bureaucracy who have an interest in promoting new public programmes, increasing funding for existing programmes or developing new types of regulations. Essentially they are a bureaucratic force working for specific sector goals within the public sector and have a propensity for increasing the range of activities provided by sub-national governments or enhancing the quality and quantity of existing services. 
- Expenditure Guardians are those actors within the bureaucracy who have an interest in macroeconomic control and restraining public expenditure and activity. They are typically central agencies, such as the New Zealand Treasury.

Inter-governmental relationships are consequently the result of processes intended to resolve tensions between the idea of local autonomy (promoted by Topocrats), sector policy goals (advocated by Expenditure Advocates), and macroeconomic control (promoted by state sector agencies concerned with macro-economic policy or Expenditure Guardians). Good public policy is achieved when a balance is reached between the three participants, that is, council autonomy is not undermined and departments achieve their policy goals while operating within a sound macro-economic and fiscal policy envelope. In the New Zealand context there is a single local government association, Local Government New Zealand, which has an undisputed mandate to represent local government's national interests. ${ }^{7}$ The Expenditure Guardian is the Treasury, the Government's financial adviser while an example of an Expenditure Advocate is the Ministry of Health. Policies promoted by the Ministry of Health frequently have an impact on council balance sheets, such as its recent policy to require councils to improve the quality of drinking water. Local Government New Zealand advocated that compliance by councils should be voluntary in order to reduce the cost, an approach that government Ministers eventually agreed with.

Political theory can also have an impact on the nature of the central-local government relationship. For example, the last two decades has seen a significant interest in decentralisation, driven by agencies like the World Bank that argue that public decision-making should be located as closely as possible to the citizens affected by those decisions, essentially the principle of subsidiarity. Subsidiarity is a normative principle in the sense that it argues that governance responsibilities should occur locally unless there are reasons, such as economies of scale or equity considerations, which justify locating responsibilities at a higher sphere of governance, either regionally or nationally. As a principle it is variously endorsed around the world, most notably in the European Treaty, which enshrines the doctrine of subsidiarity as a fundamental criterion in European law making. ${ }^{8}$ Subsidiarity first appeared in New Zealand policy discourse with the publication of the report of the Royal Commission on Social Policy (Royal Commission 1988) and its recommendation that the New Zealand government adopt subsidiarity as a policy framework. While providing a theoretical justification for local governments to argue for greater authority and autonomy it has not featured at

\footnotetext{
${ }^{7}$ Local Government New Zealand was formed in 1996 with the amalgamation of three separate associations. There are seventy eight councils, all of which are currently members.

${ }^{8}$ As an example of the principle at work see the European Charter of Local Self Government.
} 
all since the Royal Commission's proposals, which have been generally ignored by successive governments.

Where there has been greater decentralisation and/or a move to giving local government greater autonomy (such as the effect of local government reform in 2002 in New Zealand) the nature of the dialogue between central and local government has inevitably changed. Hand in hand with the idea that councils might exercise increased discretion has been the recognition that some form of mechanism to share information and discuss policy with higher level governments is necessary, leading to a consequential change in governance models. Montin (2000), for example, describes the growth of an integration list model of local government, particularly in Scandinavia, which has developed in response to national governments taking a more active role in monitoring and setting standards for local activities undertaken by councils.

Local empowerment, combined with greater integration, contributes to a picture of growing complexity in the central-local government relationship, with an emphasis on shared resources, knowledge and goals. Empowerment and integration also have an impact on the different instruments by which governments 'steer' their local governments, as noted above. This raises the practical question of how to engage with local governments, since there are likely to be numerous entities and engaging with each of them separately will have significant transaction costs. It is a situation designed for the creation of a local government association (the Topocrat) to fulfil the need for governments to find a single point of engagement and local governments to find a single voice for articulating their interests. With local government associations as the natural point of contact or engagement we are left with the question of how best to involve them in the policy and decision making process. One option is the development of guidelines or protocols. For example:

- The standing orders of the German Federal Parliament require that local government associations are consulted on legislation and policy affecting local government interests.

- The Swiss constitution declares that the Swiss Federation shall take into account the possible consequences of its actions on municipalities.

- The South African constitution provides that municipalities will have the right to comment on any draft legislation that might affect them. South African local government has also been given the right to appoint 10 members to the second parliamentary chamber where they are able to participate ex officio in deliberations.

- The local government associations in Austria, representing cities, towns and the municipalities, are recognised in that country's constitution, with the state having an obligation to involve them 
when debating European Union proposals with local implications. The Austrian constitution also requires the government to consult with local government representatives before new legislation that might have an important financial impact on councils is enacted.

- In Western Australia the state government invites councils, through their Local Government Association (WALGA), to propose projects for consideration in the state government's annual budget. The Association calls for expressions of interest from its members and evaluates projects against agreed criteria before submitting proposed projects.

- The memorandum of agreement between the Tasmanian Local Government Association and the state government includes protocols which set standards for consultation as well as a mechanism for dealing with cases where consultation may have failed.

Central-local government engagement is a process that involves a number of actors and a variety of institutional forms. As Blom-Hansen shows, one of the critical dynamics is the relative roles and status of local government associations (the Topocrats), Expenditure Advocates and Expenditure Guardians. His model caters for a situation in which there is a constant jockeying for influence between the three types of agencies. The challenge for establishing meaningful and effective relationships is to find mechanisms that reduce the uncertainty created by this dynamic and enable both spheres of government to develop mutual plans for the social and economic advancement of communities and nations.

\section{Models compared}

Internationally central-local government engagement is a very diverse territory reflecting the unique constitutional arrangements of each country, particularly their federal or unitary status. While some systems provide local government with constitutional recognition, the nature of the provisions vary with regard to how engagement is approached ranging from prescriptive to silent. Engagement is also influenced by the structure of sub-national government itself and their respective histories. There are three broad approaches - legal, political and mixed:

- The legal approach provides a legislative context for engagement, such as a parliamentary or constitutional duty to consult with local government which may go as far as to explicitly name the relevant local government association as the agency responsible for representing local government's view. The Municipal Association of Victoria (MAV) has such recognition.

- The political approach involves mutual agreement between representatives of the higher level government and local government with regard to the rules and processes for ongoing 
engagement. The most common appear to be negotiated agreements and memoranda of understanding.

- Engagement approaches do not need to be mutually exclusive and an ideal approach might very well be a mixed one, with both a legislative and political aspect, in which status is established by legislation or the constitution while practice is determined by agreement negotiated bilaterally.

A number of jurisdictions have established permanent commissions or committees for managing the local central relationship. For example:

Table 1 Structures

\begin{tabular}{|l|l|}
\hline Australia & $\begin{array}{l}\text { No constitutional recognition of local government but provides a seat for the president of } \\
\text { the Local Government Association (ALGA) on the Council of Australian Governments } \\
\text { (COAG) which meets to coordinate federal governance. }\end{array}$ \\
\hline Switzerland & $\begin{array}{l}\text { Established a 'tripartite agglomeration' consisting of the federal government, the } \\
\text { Conference of Cantons and other peak organisations for local government to coordinate } \\
\text { governance. }\end{array}$ \\
\hline Spain & $\begin{array}{l}\text { Established a Commission of Local Governments which acts as catalyst for identifying } \\
\text { municipal problems and communicating them to the government. }\end{array}$ \\
\hline Wales & $\begin{array}{l}\text { The Welsh Parliament is required to consider local government's interests in its actions. It } \\
\text { is also required to sustain and promote local government in Wales as well as to establish } \\
\text { a Partnership Council consisting of members of the Assembly and local authorities. }\end{array}$ \\
\hline
\end{tabular}

Formal entities, such as those identified above, appear to be most common in federal jurisdictions where the challenge of coordination is that much greater and engagement is multi-level, involving federal, provincial and local authorities. More common are mutually negotiated protocols and guidelines or partnership agreements. In addition to the use of formal entities the last decade has seen an increase in the use of protocols or broad ranging agreements that set out expectations of local and central governments towards each other. For example, Blom-Hansen (1999) notes that all three Scandinavian countries use agreements between central authorities and local government associations as an alternative to legal regulation; he also notes that associations in the different countries have considerably different levels of influence.

Agreements take a variety of forms. In the UK, the Central-Local Concordat signed between the Local Government Association (LGA) and British Government in December 2007 included a joint commitment by both spheres of government in England to work for better outcomes for citizens and communities as well as stating each party's rights and responsibilities in general terms. The Concordat has been replicated in both Scotland and Wales. The first step in Scotland was the formation of a Partnership Framework, agreed between the Council of Scottish Local Authorities

\footnotetext{
${ }^{9}$ The federal government has promised a national referendum in 2013 seeking approval to include reference to local government in the nation's constitution. Two previous attempts have failed.
} 
(COSLA) and the Scottish Executive in 2001 - the Framework is a non-legally binding agreement which set out principles for the purpose of forming a partnership. This has now been superseded by the Scottish Concordat, an agreement between the Scottish Executive and COSLA which focuses on commitments entered into during the life of the agreement; commitments include:

- The Government commits not to undertake any structural reform of local government;

- Local government agrees that councils will report to the Scottish Government annually on achievement of Scottish outcomes;

- The Government commits to a specific level of funding

- Councils agree to reduce bureaucracy. ${ }^{10}$

The English Concordat, signed between the Minister of Local Government in the former Labour government and President of the LGA, was more of a strategic document than the Scottish version, which has a more instrumental and practical focus (for example, 'councils will reduce bureaucracy'). It spells out the relative roles of local and central government and outlines the respective rights and responsibilities of each sector. For example:

- Central government has the right to set national policies ... and to intervene to prevent underperformance;

- Councils have the right to address the priorities of their local communities ... and shape its future without unnecessary interference;

- The partners to this agreement will come together regularly in a new local central partnership.

The concordant has not been renewed by the new Conservative Liberal Democratic government at this stage however the Political and Constitutional Reform Committee of the House of Commons has recently produced an "Illustrative Code for Central and Local Government" which is set out as the basis of a future agreement. ${ }^{11}$

\section{The Australian experience with agreements}

Agreements are widely used by states and local government associations throughout Australia. Their potential for harmonising relationships was recognised as early as 2003 by the Australian Standing Committee on Economics, Finance and Public Administration when, in their report Rates and Taxes (Commonwealth 2003), they noted that it "would be beneficial to establish formal governance

\footnotetext{
${ }^{10}$ See http://www.cvsfife.org/publications/concordat.pdf

${ }^{11}$ See www.parliament.uk/pcrc)
} 
relationships and consequent financial agreements between the levels of government" (Commonwealth 2003, p. 17). The Committee went on to argue that partnership agreements have the capacity to enable states and local governments to respond to the articulated needs of their communities through agreed plans and resources.

The Committee considers that one of the keys to reform is intergovernmental partnerships. Partnerships help to ensure that government services are effectively and efficiently delivered at the local level. They are an important step towards improving the relationship between local government and other spheres of government in the future (ibid p. 18).

Contributing to the Committee's inquiry, the Australian Local Government Association (ALGA) suggested that agreements would be able to provide more certain policy outcomes due to more predictable levels of funding; allowed better specification of performance; a greater level of transparency and provided a meaningful framework for reprioritising and reallocating resources within and across government (Commonwealth 2003).

A number of Australian States, such as Western Australia, Tasmania and South Australia, have signed agreements with their respective local government associations which are similar to the English Concordat but of more limited scope. Unlike the Concordat, these agreements tend to be more operational and take the form of a memorandum of understanding which commits each sector to particular behaviours in relation to the other, covering issues such as communication and consultation. There is also an inter-governmental agreement establishing principles for managing the relationships between all the states and the Australian Local Government Association (ALGA).

\section{South Australia}

The South Australian Agreement, negotiated between the state government and the South Australian Local Government Association (SALGA), set agreed principles and established a Ministers’ Local Government Forum to "address some of the complex and challenging issues between the two spheres of government” (Tiley and Dollery 2010, p. 33). It places considerable weight on process, such as the requirement to consult, and includes a provision for dealing with disagreements. One of the commitments agreed by SALGA is to determine the process it will use to find a sector view on topical issues. Key components of the South Australian Agreement include:

- a broad sense of purpose including the goal of enhancing efficiency, effectiveness, coordination and infrastructure;

- a desire to improve integration of strategic planning;

- a desire to foster more consistent approaches to policy and legislation;

- a recognition that disagreements will arise; 
- key principles such as mutual recognition, consultation and financial relationships (including a commitment to provide funding sources to accompany new functions);

- processes for communication and consultation;

- $\quad$ implementation and review provisions. ${ }^{12}$

The Agreement is not legally binding. It is described instead as being a statement of intent to guide attitudes and practice. It also contains a schedule of priorities which are meant to be negotiated annually between the state government and SALGA, such as a commitment for the two spheres of government to work together in areas such as strategic planning, governance and financial management, economic development and building communities.

\section{Western Australia}

The Western Australia Agreement involves the Western Australia Local Government Association (WALGA), the state of Western Australia and the WA Local Government Managers' Association (WALGA 2010). The Premier signed for the state, and the Agreement is witnessed by the Minister for Local Government and Regional Development. This Agreement consists only of three schedules, which are the partnership principles, a template for partnership agreements that can be used by other local government organisations and a framework for state local government partnerships. The overriding principle being a commitment to improving co-operation between state and local government to enhance the sustainable social, environmental and economic development of Western Australia through consultation, communication, participation, co-operation and collaboration at both strategic and project levels. Other principles deal with timely communication, purposeful consultation, the importance of partnerships and clarity around roles. Western Australia also uses agreements between the association and state government for more specific objectives, such as library provision and regional development.

\section{Victoria}

Although it lacks a specific agreement of the form found in other Australian states, the Municipal Association of Victoria (MAV) has built up a strong relationship with its state government which has resulted in the creation of a number of effective mechanisms through which it is able to influence state policy. This involves:

\footnotetext{
${ }^{12}$ See www.SALGA.asn.au for a copy of the Agreement
} 
- Regular meetings between the leaders of both sectors. The state representatives are the premier, local government minister and advisers while MAV is represented by their president, chief executive and political adviser. No minutes of the meetings are kept and no papers are prepared in advance - they are intentionally designed to allow free and frank discussion to highlight emerging issues from either sector, test out ideas and get things fixed. These meetings are a way of ensuring potential differences are recognised in advance and conflict possibly diverted. (MAV employ as a member of staff an experienced political adviser who is responsible for managing political and agency relationships.) ${ }^{13}$

- The opportunity for the MAV chief executive to brief departmental advisers and chiefs of staff on local government issues. This mechanism, which is undertaken by the Chief Executive and key advisers, allows the association to brief central government advisers on emerging issues (an early warning mechanism) and to be briefed in turn of any plans held by departments or ministers with implications for councils. The ability to play this role has been acquired over time with the association winning respect from, and building a level of trust within, the bureaucracy.

MAV has found that working closely with the state government is the best way to realise policy gains despite pressure from some member councils for the association to take a more publicly critical role. To date the board has taken the view that maintaining a constructive relationship is important in order to provide what is a unique opportunity to contribute to policy-making at an early stage.

\section{New South Wales}

In contrast, the New South Wales Local Government and Shires Association, while maintaining good working relationships with some portfolio ministers, has been unable to build any kind of formal relationship with the state premier or his office. ${ }^{14}$ Although months were spent in drafting a formal inter-governmental agreement the previous minister and premier were unwilling to sign up. In the Association's view the problem stems from political instability at the state level with four local government ministers in the last term and a centralising culture or a "state knows best" attitude (NSW still has rate pegging which is blamed for the poor state of local government infrastructure.) The recent change of government at the state level appears to also have changed the dynamics of the relationship with ministers more willing to engage. ${ }^{15}$

\footnotetext{
${ }^{13}$ Interview between the author and MAV chief executive.

${ }^{14}$ This has since improved greatly since the election of a new State Government in 2011.

${ }^{15}$ Interview between the author and association staff.
} 


\section{Tasmania}

The state of Tasmania has taken a comprehensive approach to partnership agreements, a programme that was initiated as early as 1998 and involves partnerships agreements between the state and the local government association as well as the state and individual councils. The partnership agreements program was launched in 1998 in order to "better service Tasmanian communities by the two levels of government working together" (Tiley and Dollery 2010, p. 23). There are now four types of partnership agreements:

- Bilateral - agreements between individual councils and the state government;

- Regional - agreements between regional bodies or groups of councils and the state government;

- Statewide - agreements between the LGA of Tasmania and the state government;

- Tripartite - agreements between the Australian Government, the state government and local governments.

A review of the partnership programme (Department of Premier and Cabinet 2008) made a number of recommendations for strengthening and improving the programme. The review noted that the agreement programme had met its objectives in terms of partnering with councils to deliver local outcomes; had success in addressing significant social, economic and environmental issues and had embedded more efficient service delivery across a number of policy areas. Amongst its recommendations the review suggested that the objectives of the agreements be amended to:

- Enhance the strong and cooperative relationship between the state government and local government;

- Contribute to the delivery of the state government's strategic economic, social and environmental priorities;

- Support the delivery of local government's strategic priorities at a statewide and regional level;

- Build regional capacity focusing on agreed high-level priorities;

- Identify and deliver joint initiatives that contribute to the well-being of local communities (Local Government Division 2008).

In particular officials recommended that partnership agreements: be endorsed at the highest level; be shorter sharper agreements comprising high-priority, achievable and measurable initiatives; focus on improving cohesion and coordination across agreements; link state, regional and local agreements as appropriate and ensure that major policies and programmes are supported and delivered at all levels. There was also a recognition that the regional approach to service delivery should be enhanced and an investment should be made to build regional capacity. Tiley and Dollery (2010) suggest that the 
existence of the agreements made it much easier for the state government to carry out its programme to create three corporations to manage councils' wastewater.

\section{Other jurisdictions}

Agreements are also used in Canada, for example the agreement between the Province of Ontario and the Ontario Association of Municipalities which not only sets out a mutual commitment to consult but also states the province's commitment to respect the right of councils to handle matters within their jurisdiction. A schedule of quarterly meetings to be held between the two parties is also included. The Agreement is jointly signed by the Minister of Municipal Affairs and Housing and the Association's President, and witnessed by their relative chief executives. Running to nine pages with attachments the Agreement covers the following:

- A joint commitment to policies for promoting the well-being of Ontario’s economy and society, for current and future generations;

- Recognition of a need for a coordinated response to the problems facing society, regular consultation and respect for the role of municipalities as accountable and autonomous governments in relation to activities within their jurisdictions;

- An outlined process for scheduling meetings and the manner in which the logistics will be carried out. ${ }^{16}$

The Agreement has a life of three years, includes reference to the lead agencies responsible for its administration (Dept. of Housing and Local Government and the Association) and a commitment to meet regularly. Consultation is a major component of the Agreement, particularly a commitment to prior consultation on behalf of the province, particularly where any proposed legislative or regulatory change will impact on councils’ current budget planning cycles.

The Northern Ireland Local Government Association (NILGA), still in the relatively early days of political devolution, does not yet have any formal agreement with the Northern Ireland government. While committed to establishing a statutory relationship the association is involved in three types of non-statutory arrangements (as at 2009):

- Quarterly meetings with the Local Government Minister;

- Ad hoc meetings with ministers on specific issues;

\footnotetext{
${ }^{16}$ Accessed from http://www.amo.on.ca/wcm/Documents/amo/MOU/2010Dec_MOU_Joint_Statement.pdf
} 
- The opportunity to nominate appropriate officers to participate in working groups or consultations.

At the minimum agreements tend to specify processes designed to provide surety of communication and consultation. Some go further, using agreements as a basis for negotiating future goals and targets and a local government commitment to their achievement. Yet agreements are far from universal, New Zealand being a case in point, despite the existence of an inter-governmental forum which has been in place for more than twelve years. Understanding why the political environment in New Zealand has not been conducive to some sort of inter-government agreement may improve our understanding of the factors that govern the nature of the arrangements designed to improve coordination and alignment between central and local government in other contexts.

\section{The New Zealand experience}

The model of local government which emerged out of New Zealand's colonial past was, not surprisingly, firmly based within the Anglo Saxon tradition and as such shares common features with systems in Australia, Canada, Ireland and the United Kingdom. A feature of this model is local government's legal and constitutional separation from central government. Unlike the integrated nature of governing arrangements in much of continental Europe, the Anglo Saxon approach tends to emphasise accountability to voters rather than to higher authorities. In this model, independence and autonomy are considered virtues and attempts by the centre to impose national or 'one size fits all' solutions are inevitably strongly contested. (Although, as we shall see, there are suggestions that recent and proposed policy changes are shifting the New Zealand local government model towards the more integrated European approach.)

The country's colonial roots also explain why the state plays a larger role in community life than in virtually all other OECD countries, as the cost of developing infrastructure from scratch was often beyond the small and dispersed settlements that made up $19^{\text {th }}$ Century New Zealand, leaving central government to make the investment. Even so, by the mid 1930s councils in New Zealand were responsible for half of all public expenditure, a figure that, with the growth of the welfare state, had fallen to less than $10 \%$ eighty years later. Also contributing to the relative dominance of central government was the fragmented nature of local governance that existed from the early 1850s to 1989, with local government reform in 1989 consolidating more than 850 local bodies in to 87 multipurpose local authorities. Until that point in time local governments were regarded as small and without capacity to take on additional services. As a result, New Zealand achieved the status of being the most centralised regime in the OECD (The Economist, Oct. 31, 2009). 
The existence of a fragmented local government sector made the issue of how to align and coordinate local, regional and central government policy and action all the more salient and a number of attempts were made address the issue. In 1975 a Territorial Government Consultative Group was established to initiate regular consultation and cooperation between central and local government (regional bodies were not represented - presumably because at that stage they had no national organisation). Consisting of the heads of the two local government associations and their chief executives (one representing counties which were rural councils while the other representing municipalities, which were largely urban) and the Minister of Local Government, the group provided for an interchange of views and was used by Ministers as a sounding board for various initiatives affecting councils. Sowman (1984), writing about the Consultative Group at the time, noted that it tended to focus on specific local government matters as opposed to the opportunity for local government to support broad national policies and reflected that it might take the Prime Minister to lift its focus.

The Consultative Group did not survive the tumult of local government reform in 1989, and relations over the following decade were limited to irregular meetings between the head of the Local Government Association ${ }^{17}$ and the Minister of Local Government. The prevailing view of the government of the time saw local government in largely instrumental terms as one of a range of possible service delivery bodies. It was not until the election of the Labour Government in 1999 that the importance of central-local government relationships was once again acknowledged, to such an extent that the relationship was framed in partnership terms.

A new approach to the relationship was flagged by the Labour Party while in opposition with its manifesto signalling the importance of inter-government collaboration and wanting "local bodies to operate with autonomy and freedom within a collaborative framework that allows levels of government to work for the best outcomes for communities” (Labour Party Election Manifesto 1999). It was a sentiment that surfaced strongly as it began a review of the Local Government Act 1974:

The challenges facing New Zealand in areas such as sustainable development cannot be met by central government making decisions and acting on its own. They require a partnership approach within which central government, local government, and the voluntary and business sectors can work together (Lee 2001, p. 13).

The government identified four objectives intended to guide its review of the LGA 1974; relevant to this discussion is bullet point number three, namely "involve the development of a partnership relationship between central and local government” (DIA 2001, p. 6). Once enacted the LGA 2002 was a signal that inter-government relationships were important (at least to the government of the day)

\footnotetext{
${ }^{17}$ In 1996 the Local Government Association, formed by a merger of the Counties Association and the Municipalities Association and later the Catchment Authorities Association, changed its name to Local Government New Zealand.
} 
with the result that it stimulated a flourish of initiatives designed to improve relationships, despite criticism that they did not go far enough (see Thomas and Memon 2007, Local Futures 2006).

The LGA 2002 (once again under review at the time of writing) was a significant milestone in the development of local government in New Zealand. Not only did it replace an ageing ultra vires statute with a form of general empowerment but it refocused the purpose of local government on promoting community well-being and strengthened 'social' accountability, that is, accountability to citizens through a greater emphasis on consultation with citizens, long term planning and allowing communities to set outcomes in order to steer their councils. Strengthening local government's community accountability and establishing processes to enable citizens themselves to set desired outcomes set the scene for more effective relationships with central government and its agencies. In fact the purpose of long term planning included the desire to:

- Promote better co-ordination and application of community resources;

- Inform and guide the setting of priorities in relation to the activities of the local authority and other organisations (s73, LGA 2002).

The legislation had an implicit sense of community governance suggesting that councils should be facilitating a process through which communities could influence departmental priorities. The result was a series of initiatives designed to build alignment and relationships at both a bureaucratic and political level, for example:

- A Deputy Secretaries' Group was established to coordinate engagement between central government agencies and local governments;

- An advisory group, the Local Government Interface Team, was established and located in the regions, to encourage government departments to contribute to process for identifying community outcomes and improve relationships with departments;

- The Department of Internal Affairs established a community outcomes website to highlight good examples of central-local government collaboration;

- The Department of Internal Affairs (DIA 2007) also developed guidelines to assist other departments when developing regulations that were to be implemented by local government, addressing councils' concerns about lack of consultation; ${ }^{18}$

- Regional inter-agency networks sprang up across the country with a focus on aligning local and central government investments; ${ }^{19}$

18 See http://www.dia.govt.nz/diawebsite.nsf/wpg_URL/Resource-material-Our-Policy-Advice-Areas-Policy-developmentguidelines-for-regulatory-functions-involving-local-government?OpenDocument 
- The Ministry of Social Development, established regional commissioners to better enable engagement with local authorities;

- In addition the Government made a commitment to hold a forum between the Prime Minister and relevant members of Cabinet and local government leaders twice a year to be known as the central-local government forum.

One impact of the suite of relationship initiatives was a greater willingness to involve local government representatives when central government departments were developing policies with the potential impact on councils. Involvement, however, was not uniform and often depended on the good will of departments. In fact, it was frustration with the way some departments approached engagement that led to the development of the regulatory guidelines (see above). Engagement on the ground was also patchy as government departments had centralised or regionalised to such a degree that they lacked presence in a number of council areas. The DIA local government interface team often found itself filling the gap in those districts where a departmental presence was lacking (DIA 2007). In the Auckland region, the country's largest urban configuration, the Government established an office to better coordinate its relationship with the 7 councils of the Auckland region. ${ }^{20}$ The result was that government officials played an active part in regional urban planning promoting the Government's objectives, particularly its focus on sustainable development.

Central-local Government Forum meetings have occurred since 2000 and involve the Prime Minister and relevant members of Cabinet who meet with the national council of Local Government New Zealand (the Local Government Association), which represents all the councils. ${ }^{21}$ The meetings create a space in which representatives of the two sectors can engage in dialogue as equals and the goal is free and frank discussion, although in practice that is seldom achieved. While there is an executive position of Minister of Local Government, the position is normally lowly ranked in terms of Cabinet seniority and is focussed on managing relationships in order to reduce political risk. ${ }^{22}$ In practice the Forum has provided a mechanism that allows the local government sector, through the association, to bypass the institutional filters that operate within departments, to allow sector representatives to raise concerns directly with appropriate ministers, who, with the Prime Minister as Forum chair, are frequently tasked with finding solutions.

\footnotetext{
${ }^{19}$ See community outcomes Bay of Plenty (COBOP) at www.cobop.govt.nz

${ }^{20}$ Formerly known as GUEDO it is now described as the New Zealand Government's Auckland Policy Office.

${ }^{21}$ The National-led Government has reduced the frequency of the forum to one annually.

${ }^{22}$ After the 2008 elections the post of Minister of Local Government was given to a minor party in the coalition and placed outside cabinet.
} 
The Central-Local Government Forum replicates at a governance level initiatives that occur with a degree of regularity at an officials' level. For example, the Ministry for the Environment holds an annual meeting to which all council chief executives are invited to discuss environmental issues. In recent years there have also been short-lived collaborations between officials in the area of sustainability, local government funding and social policy. The ability to influence government policy and the quality of relationships through the Forum possibly explains the lack of interest in any type of formal agreement, in addition to the original terms of reference. However, the degree of influence appears to have been strongly dependent on the Prime Minister of the time, her knowledge of local government (as a former councillor and political studies lecturer) and the dynamic of the relationship established with the President of Local Government New Zealand.

A change of government in 2008 had a major effect on the nature and style of inter-governmental relations. The new National led government was impatient for change and had little time for officials' activities that failed to lead to specific actions. Within two years the Deputy Secretaries' Group had been wound up; the Local Government Interface Team was made redundant and the central-local government forum reduced to an annual meeting, with a willingness to meet in smaller task focussed meetings. And a range of changes were made and proposed to the LGA 2002 that removed the requirement for the community to identify outcomes, refocused the activities of councils on 'so called' core services, and sought to restrict the discretion of councils to respond to local issues ultimately an attempt to down-size the local government sector. Only within Auckland did the previous configuration of government agencies working with councils continue and was in fact enhanced. Within two years of their election the Government had managed to merge the seven councils of the Auckland region into one, a large unitary council of 1.5 million residents. The expected economic potential of such a large city was seen to justify a significant policy presence in Auckland as well as an annual forum between Cabinet and the Auckland Council.

The new approach to inter-governmental relationships was epitomised by a statement by the then Minister of Local Government, the Hon Nick Smith, who stated that "the broad purpose of the LGA 2002 ... creates false expectations about what councils can achieve and confusion over the proper roles with respect to central government and the private sector" (Smith 2012, p6). The Government sees local government in strictly instrumentalist terms, responsible for the provision of narrowly defined services and finds little value in measures to promote collaboration and inter-governmental working, unless they are project focussed. In practice it appears to reinstate a more traditional command and control approach as opposed to the more indirect steering approaches now found in much of the world as noted by Kelly (2006) and Leuprecht and Lazar (2007). 
Although flagged by Local Government New Zealand in its briefing to the Government, no interest in some form of inter-government agreement or high level protocol has so far been shown. This has disadvantaged the local government sector in its efforts to influence government policy, as it affects councils and their communities, and left the nature of inter-governmental relationships seriously dependent on the style and preferences of individual actors. Disadvantage is made that much worse by New Zealand local government's weak constitutional status. New Zealand lacks a written constitution and local government's powers are set by a simple majority within parliament leading to a highly unstable legislative framework.

\section{Conclusion}

An inescapable feature of the central-local government relationships in New Zealand, as in many countries, is its asymmetry. Without a strong constitutional reference and a constitutional court with oversight, relationships exist entirely at the discretion of the national partner which has the power and authority to write the rules as it sees fit. Even where local government is constitutionally recognised national governments hold considerable scope to alter operational processes, funding and functions. Within this context it is often left to national local government associations, the Topocrats, to use what influence they can muster to ensure local governments have the legislative frameworks to enable them to fulfil their obligations to citizens. With or without the protection of some form of constitutional recognition, agreements appear to be useful mechanisms for enabling local governments influence the agenda of higher level authorities, even if all they achieve is regular contact and communication. In fact agreements themselves vary from a heavy emphasis on principles to those which are largely process driven with some jurisdictions using them to set annual targets specifically designed to influence council priority setting and decision-making.

The interface will also be influenced by the degree to which there is overlapping political membership. In many countries political parties have an active presence at the local government level providing a non-constitutional mechanism through which local members are able to influence their national colleagues and vice versa. ${ }^{23}$ Many members of national parliaments are familiar with local governments for the simple reason that they began their political careers as local councillors (generally a good idea as it helps develop political skills and experiment with policies at the local level before trying them out on the nation as a whole). That experience has the potential to create allies and advocates when matters of local government are being discussed. Similarly, where councils

\footnotetext{
${ }^{23}$ The English LGA has separate caucuses representing the three major parties and the association president is selected from the party which has the most majorities after local government elections.
} 
have a majority of councillors who are also members of the party in charge of the higher level government networks are established which can assist alignment.

Banner (2002) suggests that countries with the Anglo-American local government model are moving towards a kind of "co-operative-dualism” which holds out prospects for a sustained dialogue between central and local government. As a possible example, consider the Australian Government's Department of Regional Development and Local Government's suggestion that improving coordination is necessary to achieve better and more efficient service delivery outcomes:

Many people believe local government should have a greater role in partnering with the Australian Government in fulfilling the national policy agenda, particularly in areas such as, for example, regional development, transport and communications, environmental management and indigenous issues (Dept. of Regional Australia 2002).

Australia has the complexity of brokering relationships across three spheres of government; in contrast New Zealand is in the fortunate position of managing only two, although this is no guarantee for success. In fact recent legislative change suggests that New Zealand is moving in the opposite direction with less sustained dialogue and much more direction-setting by the centre. Yet for the sake of effective governance at the local and community level it is important that both central and local government ensure that their policies, programmes and long term investments are as aligned as possible.

If nothing else, engagement between national and sub-national governments has a symbolic value in that it reinforces the notion that local government plays a critical role in the governance of places, and that this actually matters. From a local perspective, council leaders who can show how local services contribute to the 'bigger picture', and promote the interests of the nation as well as use their position to ensure nationally provided services address local priorities, are more likely to generate support from their own constituents and enhance trust and respect in the process of government itself. Increasing confidence and trust in government while addressing local issues must be a desirable outcome.

The future success of New Zealand, and indeed all countries with multi-level governance systems, depends upon utilizing the respective strengths of government at local, regional and national levels and ensuring duplication is kept to a minimum, councils have an empowering statute to work under that does not contain unnecessary transaction costs and central government is able to focus on the strategic issues facing the nation. For this to happen there needs to be ongoing communication, acknowledgement and respect between the various spheres of government. Councils should be the 
government's eyes and ears ensuring national decision-makers are aware of the impacts of their policies outside the capital while providing feedback on the impact of policies and programmes. For the government there is advantage in being able to 'piggy back' on local initiatives.

\section{References}

Albrechts, L. (1991) Changing Roles and Positions of Planners, Urban Studies, Vol. 28 (1) pp 123 - 137

Albrow, M. (2001) Society as Social Diversity: The Challenge for Governance in the Global Age, in OECD (eds.) Governance in the 21st Century, OECD, Paris

Aulich, C. Gibbs, Melissa, Gooding, A. McKinlay, P. Pillora, S and Sansom, G. (2011) Consolidation in Local Government: A Fresh Look, accessed from www.acelg.org.au in October 2012

Banner, G (2002) Community governance and the new central-local relationship in the International Social Science journal, Vol. 54(172), pp 217-231

Blom-Hansen, J (1999) Policy Making in Central-local Government Relations: Balancing Local Autonomy, Macro economic Control and Sectoral Policy, Journal of Public Policy, 19(3), pp 327 - 264

Carman, A. (1970) The Birth of a City, Wellington

Commonwealth (2003) Rates and Taxes: a fair share for responsible local government, Standing Committee on Economics, Finance and Public Administration, Federal Government, Australia, accessed in October 2012 from http://www.localgovt.sa.gov.au/_data/assets/pdf_file/0020/596/febhawker.pdf...

DCLG (2007) UK Central-local Concordant (DCLG) Department of Communities and Local Government accessed from www.communities.gov.uk/documents/localgovernment/pdf/601000.pdf

Department of Premier and Cabinet (2008) The Partnership Agreements Program: The first ten years, the next ten years, from www.dpac.tas.gov.au/divisions/lgd/partnerhsip agreements

DIA (2001) Reviewing the Local Government Act 1974 - Have your Say, Consultation Document, Department of Internal Affairs, Wellington

DIA (2007) Policy Development Guidelines for Regulatory Functions Involving Local Government, accessed from:http://www.dia.govt.nz/diawebsite.nsf/wpg_URL/Resource-material-Our-Policy-Advice-AreasPolicy-development-guidelines-for-regulatory-functions-involving-local-government?OpenDocument

Dollery, B. and Wallis, J. (2001) The Theory of Market Failure and Policy Making in Contemporary Local Government, Discussion Paper 0121. Department of Economics, University of Otago, Dunedin, New Zealand (Unpublished)

Fannie Mae Foundation (2007) States and Their Cities Partnerships for the Future, The Fannie Mae Foundation

Gormley, (W) Money and Mandates: The Politics of Inter Governmental Conflict, in Publius: the Journal of Federalism, volume 36 (4), pp. 523-540

Kennett, P (2010) Global Perspectives on Governance, in Osborne, P. (ed) The New Public Governance? Emerging perspectives on the theory and practice of public governance, Routledge London and New York

Kjaer, A. (2004) Governance, Polity Press, Boston, MA

Leuprecht, C., and Lazar, H., (2007) Multilevel to Multi-order Governance, in Spheres of Governance: Comparative Studies of Cities in Multi-order Governance Systems, accessed from www.queens.ca.iigr/pub/Book/Spheres/5plusintro.pdf

Local Futures (2006) Local Government, Strategy and Communities, Institute of Policy Studies, Victoria University Press, Wellington

Local Government Division (2008) The Partnership Agreements Program: The first ten years, the next ten years, Department of Premier and Cabinet, Tasmania 
Loffler, E. (2003) Governance and Government, in Bovaird, T., \& Loffler, E. (eds.) Public Management and Governance, Routledge, New York

Lyons, M. (2007) Place-shaping: A Shared Ambition for the Future of Local Government Final Report, The Stationery Office, London

Montin,, S. (2000) A Conceptual Framework, Towards a New Concept of Local Self Government? Amna, A., and Montin, S., (eds.) Fagbokforlaget, Bergen

Oates, W.(1972) Fiscal Federalism, Harcourt Brace Jovanovich, New York

OECD (2010) Better Regulation in Europe: Ireland, viewed from http://www.oecd.org/regreform/regulatorypolicy/46271933.pdf: October 2012

Peters, G and Pierre, J. (2001) Development sin intergovernmental relations: towards multi level governance, in Policy \& Politics, Vol. 29 (2), 131 - 5

Roberts, N. (2000) Wicked Problems and Network Approaches to Resolution, International Public Management Review, Vol. 1(1), pp. 1-19

Royal Commission on Social Policy (1988) Towards a Fair and Just Society, Royal Commission on Social Policy, Parliament, Wellington

Smith, N. (2012) Better Local Government, New Zealand Government accessed from www.dia.govt.nz, October 2012

Sowman, R. (1984) Paternalism or Partnership, Central Government's Administrative Attitude to Local Government, New Zealand Planning Council, Wellington

Tiley, I. Dollery, B., (2010) Historical Evolution of Local Government Amalgamation in Victoria, Tasmania and South Australia, Working Paper Series, Centre for Local Government, University of New England, Armidale, NSW

Thomas, S., \& Memon, A. (2007) New Zealand Local Government at the Cross-roads? Reflections on the Recent Local Government Reforms, Urban Policy \& Research, Vol. 25 (2), pp. 171-185

WALGA (2010) An Agreement to Guide State - Local Government Relations on Local Government Matters, accessed from www.walga.asn.au, WALGA (Western Australia Local Government Association) 